\title{
The Arab Spring: Malaysian Responses
}

\author{
Osman Bakar*
}

The Malaysian public generally, and political observers and academics in particular, have been following the unfolding of events in the Arab world - the so-called Arab Spring - since the beginning with great interest and also deep concern. There was great interest among Malaysians, because the phenomenon was unexpected and extraordinary. They do feel that the Arabs deserve a real change for the better, especially in the political sphere. However, like many Arabs themselves, they are used to being pessimistic about genuine change in the Arab world. With this kind of pessimism, many Malaysians see the eruption of the people's protests as something unexpected. When the protests end with victory in the sense of their having achieved the target of removing the top leaders from power, as in the case of Tunisia, Egypt, and Libya, Malaysians express concern and wonder whether the hard-won victory will be squandered by whoever they may be. They have been asking themselves whether a real transition to a better era will indeed take place. Looking from outside, they see many uncertainties in Tunisia, Egypt, and Libya. Tunisia, however, is viewed slightly differently as having managed its transition uncertainties a little better compared to the other two countries.

The Malaysian interest and concern is understandable. As a Muslim-majority country, Malaysia has developed and cultivated multi-dimensional relationships with the Arab world for centuries that date back to the establishment of the first Muslim state in the Malay-Indonesian world in the thirteenth century. There is a wide recognition in Malaysia and its neighbours that a special kind of cultural bond exists between them and the Arab world. Long and strong relationships exist between Malaysia and the Arab world especially in the fields of religion, education, and economics.

In education, Malaysia sends a large number of its students to study in the Arab world. The majority of them pursue Islamic studies in Egypt and Saudi Arabia. However, a notable number are also found in Jordan, Morocco, and Syria. Malaysia has also sent students to Egypt to pursue medical studies. It was the student factor that first made the Malaysian public deeply aware and concerned about the wave of antigovernment demonstrations in various Arab countries. With the escalation of antiMubarak protests and Cairo becoming chaotic, the Malaysian government took the step of airlifting the more than ten thousand of its students in Egypt to Kuala Lumpur

* Osman Bakar is the Deputy CEO of IAIS Malaysia and Emeritus Professor of Philosophy of Science at the University of Malaya, Kuala Lumpur. This viewpoint is based on a brief paper presented by its author at the 'Second Dialogue for the Future between Japan and the Islamic World', held at the University of Jordan, Amman, between 29 February and 1 March 2012, and co-organised by the University of Jordan and Japan's Ministry of Foreign Affairs. 
via various stopovers. This massive airlift made many Malaysians more aware of the level of their countrymen's presence in Egypt's tertiary educational institutions, especially in Cairo and Alexandria where most of the protests took place.

Besides education, there was and there is still a visible and significant political dimension to the relationships between Malaysia and the Arab world. In the past, important events of a political or religious nature in the Arab world have always had significant impact on Muslims in Malaysia. Events leading to the break-up and the end of the Ottoman state, of which many contemporary Arab states were once parts, the post-Ottoman turmoil in the Arab world, the pan-Islamic movement initiated and nurtured in the region, the creation of Israel and the ensuing Palestinian issue, all have had great impact - sometimes violent - on Malaysia and its region. Both Islamic and secular nationalism in Malaysia (then Malaya) that found political expression in the struggle against Western colonialism were largely inspired by ideas and events current in the Arab world and Turkey.

So, not surprisingly, some people have posed the question whether the Arab Spring has any meaningful effect on Malaysia, particularly its Muslim community. On the whole, we could say that there is an impact on the Malaysian political consciousness as can be seen in the various reactions of its people, including the attempt by some groups to indigenise the issues that constitute the core concern of the Arab Spring. Malaysian reactions to the whole phenomenon were varied. Across the country's political spectrum, we have the ruling coalition government (Barisan Nasional, National Front) headed by the Prime Minister, Dato' Sri Mohd Najib Tun Abdul Razak, taking the cautious attitude of not outwardly expressing support for either the rulers or the protesters. This "neutral" attitude seems to have something to do with the longstanding policy of the Malaysian government of not meddling in the internal affairs of other countries. Some observers of the Malaysian political scene, however, are of the opinion that the ruling coalition's "neutral" position is also dictated by internal political considerations. It is widely known that the leader of the opposition, Datuk Seri Anwar Ibrahim, and PAS (Malaysia's 'Islamic party'), his party's partner in the opposition coalition, have close relations with the Muslim Brotherhood in the Arab world. Anwar Ibrahim in particular has long cultivated close relationships with many top leaders of the movement in Egypt and Tunisia. The ruling coalition is also aware of the unpopularity of the Ben Ali, Mubarak, and Gaddafi regimes among many Muslims in Malaysia, including its own supporters.

In contrast to the ruling coalition, the opposition coalition expressed open support for the Arab Spring. Their members even staged demonstrations to express solidarity with the protesters and opposition groups in Tunisia, Egypt and Libya. The Malaysian opposition's support for the Arab Spring was motivated by several considerations. The main ones were support for democracy and good governance. These are issues that cut across religious differences. It is true, however, that in the case of PAS, its 
support is also dictated by religious considerations. It harbours the hope that the Muslim Brotherhood will be the key player in the post-Arab Spring politics of the Arab world.

Civil society groups that generally support movements for democracy and good governance in the world also expressed their solidarity with the Arab Spring. For the general Muslim population, in making up their minds whether or not to support the Arab Spring, it is important that they can identify individual Muslim leaders of repute whom they can associate with the new regimes. Rashīd al-Ghannūshī, a cofounder of the Ennahda Movement, now the largest party in Tunisia, and Yūsuf al-Qaraḍāwī, a well-known religious scholar and a leader of the Muslim Brotherhood, are two such leaders for them. Al-Ghannūshī is well-known in Malaysia among the Islamic movement groups. His writings are widely read. Many Muslims express support for the protest movement and the new regime in Tunisia because al-Ghannūshī is associated with them. Now that al-Ghannūshī's party is the key player in the new government, many Malaysian Muslims are becoming more supportive of the changes taking place in Tunisia. As for al-Qaraḍāwī, he is an even more popular figure in Malaysia. His face and his books are familiar to millions of Muslims in the country. At a time when many of them were not sure who really were the leaders behind the Arab Spring in Egypt, it was comforting enough for them to see al-Qaraḍāwī leading the Friday congregational prayer at Tahrīr Square in Cairo on 18 February 2011 - the first time since he was banned from leading weekly Friday prayers in Egypt thirty years ago - so as to associate Islam with the protest movement.

Then there were the reactions of the academics, policy analysts, and specialists on the Arab world. Dr Chandra Muzaffar, Malaysia's leading intellectual-activist, described the Egyptian revolution as "the triumph of humanity". He attributed the Arab Spring to a combination of many causes, the most important of which are elite corruption and nepotism and deep-seated hatred of Israeli arrogance and United States hegemony. Several research institutes have organised public lectures delivered by speakers from the Arab world and roundtable discussions with the view of trying to better understand the Arab Spring in terms of its underlying causes, its key players, and its aftermath. These events were also aimed at gauging the opinions of the Malaysian public. IAIS Malaysia itself organised two events, one a public lecture by an Arab scholar from Saudi Arabia specialising in international relations, Dr Abdul Hamid Abu Sulayman, who has close connections with the Muslim Brotherhood, and another by Dr Sean Foley, a young American scholar specialising in the Middle East, who happened to be in Kuala Lumpur doing research as a Fulbright scholar at ISTAC (a research institution of Malaysia's International Islamic University, IIUM).

Both lectures were of great interest to the audience. Abu Sulayman talked about the post-revolution scenario and the type of government that should prevail in the Arab world. He argued that what the Arabs - and Muslims generally - need is a "civil" 
government that is religious, and not a theocratic or secular government. His ideas on state power and government do not go well with the conservative and traditional segments within the Muslim Brotherhood. He seems to favour the Turkish model of government under Recep Tayyip Erdoğan.

Dr Foley dealt with the role and impact of the young in the Arab Spring. He spoke of the Arab Spring as a youth phenomenon and argued that the success of the protest movements in Tunisia, Egypt, and Libya have a lot to do with the new pan-Arab youth culture generated mainly by the information technology that has rendered state control of information meaningless. He also referred to contemporary Arab music as a powerful medium of youth protest.

Also worthy of mention is the role of the national mainstream media both in its news coverage of the Arab Spring as well as in conducting forums and discussions on the political transformations taking place in the Arab world. A few TV channels aired forums on the Arab Spring that were participated in by invited academics knowledgeable about the region. Furthermore, thanks to media technology, many Malaysians, especially in the cities, have access to Al Jazeera, CNN and BBC to enable them to have up-to-date news and discussions on the Arab Spring. Several Malaysian personalities from academia and the political world are known to have been interviewed by Al Jazeera and CNN concerning the political turmoil in the Arab world.

\section{Recommendations}

Many Malaysians continue to follow events and developments in Tunisia, Egypt, and Libya with interest. However, Muslim research organisations concerned with the future of the Arab world, which is the heartland of the Muslim world, need to:

- understand at a deeper level the underlying causes of the Arab Spring;

- $\quad$ explore ways in which Islamic intellectual heritage may be of great help to the post-revolution leaderships of the three countries in addressing issues of constitutionalism, governance, and legal systems that are now demanding their attention;

- monitor closely post-revolution developments in the Arab-Israel relations as well as the disturbing events in Syria. 